\title{
Project-based Learning Activities and EFL Students' Productive Skills in English
}

\author{
Ni Luh Putu Ning Septyarini Putri Astawa \\ English Education Department, Ganesha University of Education, Bali, Indonesia \\ Luh Putu Artini \\ English Education Department, Ganesha University of Education, Bali, Indonesia \\ Putu Kerti Nitiasih \\ English Education Department, Ganesha University of Education, Bali, Indonesia
}

\begin{abstract}
This article presents the results of a study on the effect of Project-Based Learning on students' English Productive Skills and how the activities influence teaching and learning process in a public junior high school in Bali-Indonesia. This research applied an embedded mixed-method design in which the quantitative data were collected using speaking and writing tests, and the qualitative data were collected using interview guide, observation checklist, open-ended questionnaire, and field note. Paired-sample t-test was used to analyze whether or not there is a significant difference in students' English productive skills before and after being taught using PBL; while the qualitative data were analyzed descriptively. The results of the analysis showed a significant effect of PBL on students' English productive skills. From the part of the students, PBL was found to improve enthusiasm, confidence, creativity, self-directed learning and collaborative learning skills. On the part of the teacher, PBL promotes teaching motivation and satisfaction. This study recommends the implementation of PBL in EFL context, especially in an attempt to improve students' ability to speak and write in English as a foreign language.
\end{abstract}

Index Terms-project-based learning activities, English as a foreign language, English productive skills, teaching and learning process

\section{INTRODUCTION}

Constructivism is one of the theories which is addressed to describe the learning process according to 21 st century learning foundation. It believes on the importance of reflection on experiences towards the quality of learning (Weld \& Funk, 2005). The student, as the creator, will create their own concept and beliefs towards knowledge based on their prior knowledge (Weegar \& Pacis, 2012). Meanwhile, the teacher, as a facilitator, should provide opportunities for collaborative works and authentic tasks which enhance students' problem-solving skills (Ndon, 2011). The students are encouraged to engage in a collaborative learning situation since the teachers' role is limited in the constructivist learning. It means, instead of focusing on teacher, learning should occur in students-centered learning activities.

Communication is also one of the key components of 21 st century learning (Greenhill, 2010). One of its concerns is on student ability to effectively express their thoughts or ideas using oral and written communication skills. Both of those skills are powerful and extremely useful for the learners to prepare themselves for facing their real-life (Jerald, 2009). Strategies to communicate is influenced by the topic communicated, the interpersonal relation between the people involved in the communication, or the context (i.e. whether the situation is formal or informal) (Celce-Murcia, Dornyei, \& Thurrell, 1995). Thus, language learners are considered successful language speakers when they can perform communicative functions appropriately in various situations.

Oral and written skills are categorized as productive skills which require learners to produce rather than receive information through language (Spratt, Pulverness, \& Williams, 2005; and Harmer, 2007). In the language educational setting, through speaking and writing activities, students are given the opportunity to experience with the target language. They are encouraged to express meaning by producing appropriate oral or written utterances. In speaking, a person interacts with others or influence someone by saying something which may affect someone else's point of view or thought (Clark \& Clark, 1997). While Harmer (1991) considers writing as the only language skill which enables students to produce a touchable and readable product. As both speaking and writing involve the activity of 'producing' language in the context of communication, these skills are commonly labelled as language productive skills.

The use of a wide range of techniques to create a new knowledge, thought, or idea is also one of the bases of great teaching according to 21st century education (Jerald, 2009). It is an important process in which learners make connection across domain of knowledge. The students play an important role to develop their knowledge where they innovate their own ideas to create new things and or adapt new situation (Zhao, 2009). Every experience that is encountered in students' learning process will become a useful knowledge and those are considered as educative experience if they are organized from an authentic context (Dewey, 1938). 
The importance of students' role in the learning process is also stated in Indonesian Regulation of National Education Standard (PP. No. 19 Th. 2005, Pasal 19, Ayat 1). Learning process should be organized in an interactive, inspiring, fun, and challenging environment. The learning activities are expected to be able to provide sufficient space for innovation, creativity, and independence. Learners develop their own learning by being attached into several range of activities in accordance with their talents, interests, physical, and psychological development.

The potential strategy to maximize students' role in learning should take into account the principles of constructivism, and one of the mostly used is Project-Based Learning (PBL). PBL is simply defined as a learning strategy which is organized around projects (Thomas, 2000; Larmer, Markham, \& Ravitz, 2003; Bell, 2010). In PBL classroom, students plan, implement, reflect, and evaluate their own learning by working on authentic tasks, such as solving problem or task which is constructed based on real-world issues (Blank in Blank \& Harwell, 1997; Dickinson, et al., 1998; Westwood, 2008). PBL also elevates student's willingness in learning. According to Blumenfeld, et al. (1991), a successful implementation of PBL in the classroom can raise students' motivation by being fully involved and engaged to the classroom activities.

In its implementation, PBL has sets of steps that should be carried out (Stoller, 1997; Korkmaz \& Kaptan, 2001). Firstly, the learners and teacher make an agreement and decision about the theme or topic of the project and the method of solving the problem. Secondly, students design the project by enquiring information related to the project, the plan, and the objective of the project. Thirdly, the students collect, analyzed and organized data to answer the problems or the tasks. They create the project based on the application of the knowledge they achieve through the process of enquiring. Fourthly, the students define the essential point of the project and plan the presentation method. Fifth, the students design the presentation by analyzing and compiling the essential information about the project. Next, the students present their project by using their communicative skills. Finally, the students evaluate their learning. Though these steps, students are trained to become an active and creative thinker and are involved in collaborative learning to work on the group project.

As the students engage in the social aspects of PBL, in the same time they are also developing their 21 st century skills in which two of them are students' oral and written skills (Barron et al, 1998; Markham, 2011). Throughout the entire process of PBL, students' communication skill is being activated (Hadim \& Esche, 2002; Harun, 2006). Specifically, the students' communication skills are promoted through some activities such as sharing information, discussing the project, dividing tasks on each group member, writing essay or presentation, presenting the project result, and so forth (Guven, 2014).

To cope with the demand of educational new paradigm, learning specifically in Indonesia should be held in the way based on the 21 st century learning and Indonesian national education standard. The old paradigm of teacher-centered should be shifted into students-centered learning (Kember, 2009; Attard, et al., 2010). Unfortunately, there are some educational institutions in Indonesia that do not implement teaching and learning process as the way it supposes to be. Such facts were found on some review of studies (Pradanar, 2014; Wulandari, 2014; Yaman, 2015). Those studies proved that the lack of the teachers' knowledge about appropriate methods that can be used in teaching is the obstacle in creating an effective teaching and learning process.

The lack of teachers' knowledge on alternative strategies that reflect the 21 st century learning cause some disadvantages. Some research administered in Indonesia found the use of conventional teaching strategies that hardly help students develop collaboration, creativity, communication, and critical thinking. Conventional teaching tends to be textbook oriented and causes students to have less creativity in doing their work (Hastuti, 2016). A non-authentic material and conventional teaching methods also influence students' low motivation in learning process. They become unmotivated as the result of the small amount activities that students' attracted with (Ferti, Adiyalmon, \& Ranti, 2014). Those students who experience learning in such situation and condition will tend to have low learning achievement.

The empirical evidences presented above indicate that the process and result of learning are highly related with the teachers' teaching strategies (Guerriero, 2017). Students are being attached with the strategy in the classroom while also create their own thought about the activities they should participate in. Students will respond to the learning positively if they believe on the process of learning itself (Henter, 2014), otherwise it causes some disadvantages on the learning process.

In most public schools in Indonesia, teacher-centered learning is the most observable practices. Students mostly work on the provided tasks in the textbook. As the consequence, students were unmotivated and demonstrated low enthusiasm to participate in learning activities in the classroom. From the open-ended questionnaire, it was found that the students generally had lack of motivation towards learning and most of the students felt weary to join such monotonous learning activities. Those findings are also supported by the result of the interview with the teacher. The data reveal that teachers have the preference of using tutoring and direct-instruction strategies to teach the students. Both of those strategies are teacher-centered in nature, which make students passive and reluctant to work on their own. The strategy that is fully directed by the teacher will not teach students to be responsible to their own learning (Carnine, 2000; Knowles, 1984).

In a well-organized direct instruction, the teacher is the one who decide what is to be learned, to explain the way to do the task, actively monitor and give feedback to students' work while students are engaged in activities such as working on tasks and response to the teachers' instruction (Christenson, Ysseldyke \& Thurlow, 1989). It is inversely proportional to the theory of constructivist and it does not engage with student cultural resources, background knowledge and community context (Luke, 2013). There are some features of direct-instruction that fit in the teacher-centered 
characteristics. Direct instruction as a teacher-centered method, sets the teacher as the one that has main power in the teaching and learning process, in which he/she supposed to encourage the students construct their own learning. Instead of having discussion and conversation with the students to develop their ideas, the students are assumed to have little useful knowledge. As the result, the teachers tend to present the facts to students directly, give students less opportunity to have their own choices, and provide every piece of information that is needed by the students (Poplin, 1988; Stainback \& Stainback, 1992; Steffe \& Gale, 1995; Abdullah et al, 2012).

To cope with the problem above, the use of appropriate teaching strategies is very important. The strategy is not only expected to bring positive effect on students' academic achievement but also will train them to take responsibility on their own learning as well as to experience learning by doing. According to the previous studies related to this research, PBL brought enhancements for the students, along with the advantages. Firstly, Imtiaz and Asif (2012) proved that PBL played an important role in improving students' language skills and promoting students' autonomous learning skill in Pakistan. Secondly, Vicheanpant and Ruenglertpanyakul (2012) showed an effective effect on developing Thai students' communication skill which came along with more positive attitude in learning. Thirdly, Nassir (2014) verified significant difference on Iraqi students' English achievement before and after being taught by using PBL. Fourthly, Rochmahwati (2016) specifically found a positive impact on Indonesian students' English speaking skill before and after being taught by using PBL. The finding came along with the positive improvement on students' attitudes on language learning.

Those studies confirm that PBL can be used to teach English. However, previous studies that have been conducted before were not specifically proposed in analyzing the effect of PBL on students' productive skills and identifying the influence of PBL towards teaching and learning process. This study aimed at answering two research questions: (1) Is there any significant difference in students' English productive skills before and after being taught using PBL?, (2) How does PBL instruction influence teaching and learning process?

\section{METHODOLOGY}

The design of this study is embedded mixed-method which focuses on collecting, analyzing, and mixing both quantitative and qualitative data. The two data sets were collected during single study and they were purposed to answer two different research questions. Twenty-eight students of the seventh grade participated in this study. The quantitative data play major role within overall design. They were collected from pre-test and post-test. The result of the quantitative tests were used to analyze whether or not there is a significant effect on students' English productive skills before and after being taught using PBL. Interview, observation checklist, open-ended questionnaire, and field note were used to collect the qualitative data. The qualitative data collected before, during, and after the intervention, were used to identify the influence of PBL on teaching and learning process. Paired sample t-test was used to analyze the quantitative data, while the analysis of qualitative data followed Miles and Huberman's (1994) flow model which consists of data reduction, data display, and conclusion drawing.

\section{FINDINGS AND DisCUSSION}

The first research question was answered by examining whether or not the results of the tests before and after the treatments are significantly different. The speaking test was divided into two categories, monologue and dialogue test. The findings of the speaking and writing are presented as below.

\section{A. The Effect of PBL on Students' Speaking Skill}

The first research question was proposed in order to find out the effect of PBL on students English productive skills. Pre-test and post-test of speaking and writing were administered before and after the students were being taught using PBL. Speaking skill was divided into monologue and dialogue. The findings are presented in the tables below:

TABLE I

RESULT OF MONOLOGUE PAIRED-SAMPLES T-TEST

\begin{tabular}{|c|c|c|c|c|c|c|c|c|}
\hline \multirow{3}{*}{ Monologue Test } & \multicolumn{5}{|c|}{ Paired Differences } & \multirow{3}{*}{$t$} & \multirow{3}{*}{$d f$} & \multirow{3}{*}{$\begin{array}{l}\text { Sig. } \\
(2-t a i l e d)\end{array}$} \\
\hline & \multirow{2}{*}{ Mean } & \multirow{2}{*}{$\begin{array}{l}\text { Std. } \\
\text { Deviation }\end{array}$} & \multirow{2}{*}{$\begin{array}{l}\text { Std. Error } \\
\text { Mean }\end{array}$} & \multicolumn{2}{|c|}{$\begin{array}{l}\text { 95\% Confidence Interval of } \\
\text { the Difference }\end{array}$} & & & \\
\hline & & & & Lower & Upper & & & \\
\hline Pretest- Posttest & -26.286 & 6.749 & 1.275 & -28.903 & -23.669 & -20.61 & 27 & .000 \\
\hline
\end{tabular}

The first result of paired-sample t-test answers the first research question specifically on monologue speaking test. Paired-sample t-test was conducted for pre-test and post-test. Table 1 presents $t=-20.610$ and the Sig. (2-tailed) value is less than $0.05(0.000<0.05)$. It indicates that the participants showed a significant achievement on monologue speaking test before and after treatment. Similar test was run for the results of dialogue speaking test as presented in the following table. 
TABLE II

RESUlT OF DiALOGUE PAIRED-SAMPLES T-TEST

\begin{tabular}{|c|c|c|c|c|c|c|c|c|}
\hline \multirow[b]{2}{*}{ Dialogue Test } & \multicolumn{5}{|c|}{ Paired Differences } & \multirow[b]{2}{*}{$T$} & \multirow[b]{2}{*}{$d f$} & \multirow[b]{2}{*}{$\begin{array}{l}\text { Sig. } \\
(2-\text { tailed })\end{array}$} \\
\hline & Mean & $\begin{array}{l}\text { Std. } \\
\text { Deviation }\end{array}$ & Std. Error Mean & \multicolumn{2}{|c|}{$\begin{array}{l}95 \% \text { Confidence Interval of the } \\
\text { Difference }\end{array}$} & & & \\
\hline Pretest- Posttest & -23.286 & 5.868 & 1.109 & -25.561 & -21.010 & -20.998 & 27 & .000 \\
\hline
\end{tabular}

Table 2 presents the outcomes of the paired-sample t-test of students' dialogue speaking achievement. Pre-test and post-test results were compared in order to see the difference before and after the treatment. It shows that significant value of 2-tailed was less than $0.05(0.000<0.05)$. It can be concluded that there is a significant effect of PBL on participants' dialogue speaking test. In other words, the implementation of PBL in EFL classes significantly affect students' productive skills in English. This is in line with a similar research conducted by Yang and Puakpong (2016) who involved eighty students in Kaili University. They found that that there was a positive effect of PBL on non-English major Chinese students' speaking ability. Another positive outcomes of students' opinion towards PBL implementation in the classroom was also revealed.

\section{B. The Effect of PBL towards Writing Skill}

To answer the second research question, paired-sample t-test was also used to compare between the writing scores from pre-test and post-test. Table 3 reports the mean difference is -22.786 with Sig. (2-tailed) is $.000<0.05$. It can be concluded that there is a significant effect of the implementation of PBL on students' writing skills. This was proven by the significant difference between the mean scores before and after being taught using PBL. This finding is summarized in the following table.

TABLE III

RESULT OF WRITING PAIRED-SAMPLES T-TEST

\begin{tabular}{|c|c|c|c|c|c|c|c|c|}
\hline \multirow{3}{*}{ Writing Test } & \multicolumn{5}{|c|}{ Paired Differences } & \multirow{3}{*}{$T$} & \multirow{3}{*}{$D f$} & \multirow{3}{*}{$\begin{array}{l}\text { Sig. } \\
(2 \text {-tailed })\end{array}$} \\
\hline & \multirow[t]{2}{*}{ Mean } & \multirow[t]{2}{*}{ Std. Deviation } & \multirow{2}{*}{$\begin{array}{l}\text { Std. Error } \\
\text { Mean }\end{array}$} & \multicolumn{2}{|c|}{$\begin{array}{l}95 \% \text { Confidence Interval } \\
\text { of the Difference }\end{array}$} & & & \\
\hline & & & & Lower & Upper & & & \\
\hline Pretest- Posttest & -22.786 & 9.163 & 1.732 & -26.339 & -19.233 & -13.159 & 27 & .000 \\
\hline
\end{tabular}

The significant effect of PBL on students' writing skill was also concluded by Sadeghi, Biniaz, \& Soleimani (2016) in their research that revealed that there was a positive effect of PBL in enhancing students' comparison/paragraph writing skills. The result of their research indicated that the students who were educated by PBL performed better in their writing skill than the students who were educated by the instruction based on students' textbook.

\section{The Effect of PBL on the Teaching and Learning Process}

In order to answer the second question, the qualitative data were needed in this study. The main qualitative result was analyzed from observation checklist, open-ended questionnaire, and field note. Observation checklist was taken in order to identify students learning in the classroom. It was composed based on Thomas (2000) theory on the characteristics of PBL and Brown (2008) on the characteristics of an active learning. The open-ended questionnaire was administered in order to see how the students responded PBL activities in the end of every treatment. To gain the qualitative data from the teacher's perspective, the field note was filled along the process of every treatment.

The findings showed that PBL could promote students' enthusiasm, confidence, creativity, self-esteem and collaborative learning ability. Students' action in the classroom (which is noted in the observation checklist) shows that they enjoyed the learning process, considering on their active participation throughout the lesson. The twenty-eight participants who responded to the open-ended questionnaire showed willingness and enthusiasm to participate in the learning process. They worked in groups and create a project collaboratively. Their enthusiasm was confirmed through an interview conducted after the class. One of the students said: "I feel excited to learn because there are many creative things to do while learning" $(S 12 / F)$. Enthusiasm can also be seen in the following picture. 




Fig. 1 The students were participating enthusiastically in the process of finishing the project

The image shows that each of the students was directed to work on different kind of tasks with the aim to produce a group project. All students have their job description and were actively participated toward the accomplishment of the project. This finding supports the previous data which indicates the influence of PBL on students' learning quality in term of students' enthusiasm.

This finding was consistent with Erdem (2012) who found that PBL could promote students' enthusiasm towards learning. She stated that Project-Based Learning was able to increase students' enthusiasm towards learning. When the children are excited and enthusiastic about what they are learning, they often get more involved in the subject, the level of anxiety is reduced and then expand their interest to other materials. Enthusiastic students tend to retain what they learn, not to forget it as soon as they have passed the test.

The qualitative result also shows that PBL enhances students' confidence in practicing their English as they work collaboratively in team and helped each other. The students were continually exposed to some activities that acquired them to be able to speak their ideas to others. It was also enable students from different levels of proficiency to work and learn together. The particular finding was represented by following quotation: "I feel more confident when I present the work in front of the classroom because we are able to help each other in a group." (S09/M). Their confidence in presenting their work can also be seen from the following picture.

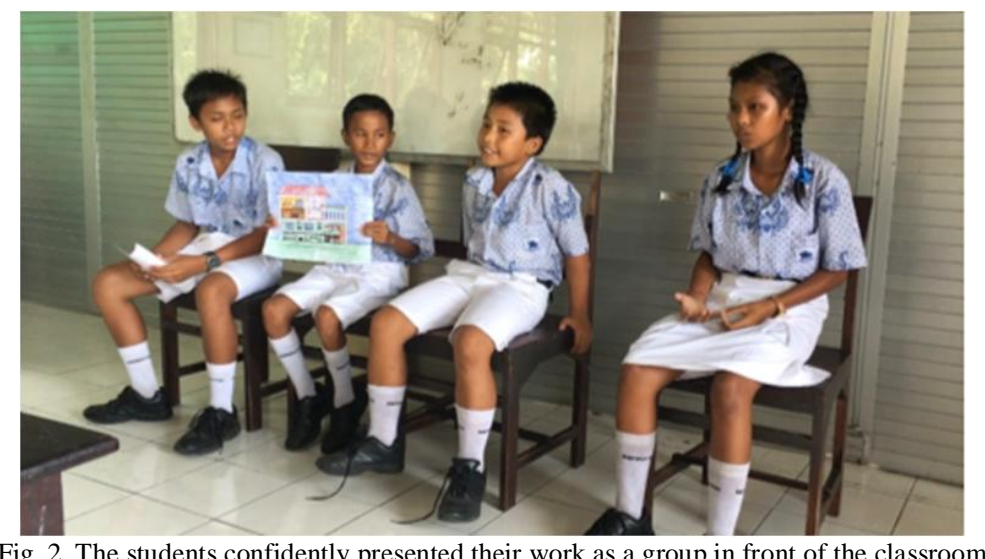

The figure above shows the students presentation on their project. All of the students were able to explain / describe their project in front of the classroom without any hesitation. In the group presentation, the students helped each other to make the presentation ran well. They also support one another when answering questions from other groups or the teacher. This phenomenon was found to support the positive effect of PBL implementation on students' learning confidence.

In relation to students' learning process, it was evident that students' confidence appeared as the result of the implementation of Project-Based Learning. One of the significant studies entitled "English Games as a Constructivist Approach in Project-Based learning" which was conducted by Masrom and Yusof (2013) also found that there was a significant positive result of working in groups in PBL class on student self-confidence. By working in a group, the students did not only build confidence but more importantly, they learn to organize work as a team and work with commitment and responsibility.

The results also show that PBL influenced students learning process by promoting their creativity on learning. The learners were assigned to work on a project which promotes their higher order thinking skills. For example, in the project of making a family profile, the students were encouraged to be as creative as they could without neglecting the essential 
meaning of a profile itself. Students' creativity is also represented through their works (Figure 3). From the open ended questionnaire it was revealed that students were aware of the need to be creative for a quality project. One the students said: "I know how to make my family profile. I took photos from my family album and then wrote in English. I must be creative so that our project is good" (SO5/F). The following picture represents student project on the topic of family profile.

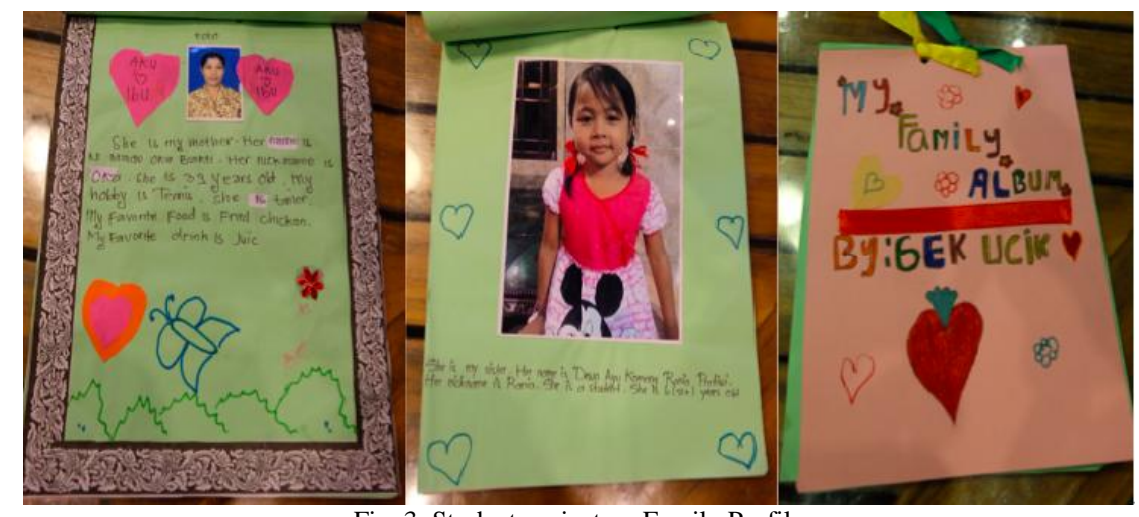

Fig. 3. Student project on Family Profile

These images represent students' creativity in doing their work. In the projects students were able to put every piece of information that was gained from the interview with their own family members. By using the result of the interview, they were able to compose some description about their family members which were all done in English. They were also given a chance to decorate their own family profile as creative as they can.

Creativity in PBL activities were also reported by Talat and Chaudhry (2014), who found that after treated with PBL model of teaching, students developed creativity as indicated by creative ideas and language use. It was also found that students creatively were especially motivated by new challenge created by the teacher. The students did their best effort to find new ideas or thought for the quality of the project. Every single individual was fully engaged during the teaching and learning process.

Students' self-esteem and collaborative learning skills are also influenced by PBL. It was evident that students were not only aware for the need to learn together as a group/team but also the initiative and responsibility for their own learning. While working in a group, the students may be involved in asking and answering questions, giving opinion about other people/group work, sharing information, evaluating other student's /group's work, expressing ideas, monitoring team work, actively interacted to make decision, etc. Individually, each student was given a chance to select and manage their own work. These activities can be expected to maximize independent and self-directed learning. Student awareness was represented by the following quotation: "The strength of this learning is that I am able to share my ideas with my friends in the group $(S O 6 / M)$. This is revealed in the following figure.

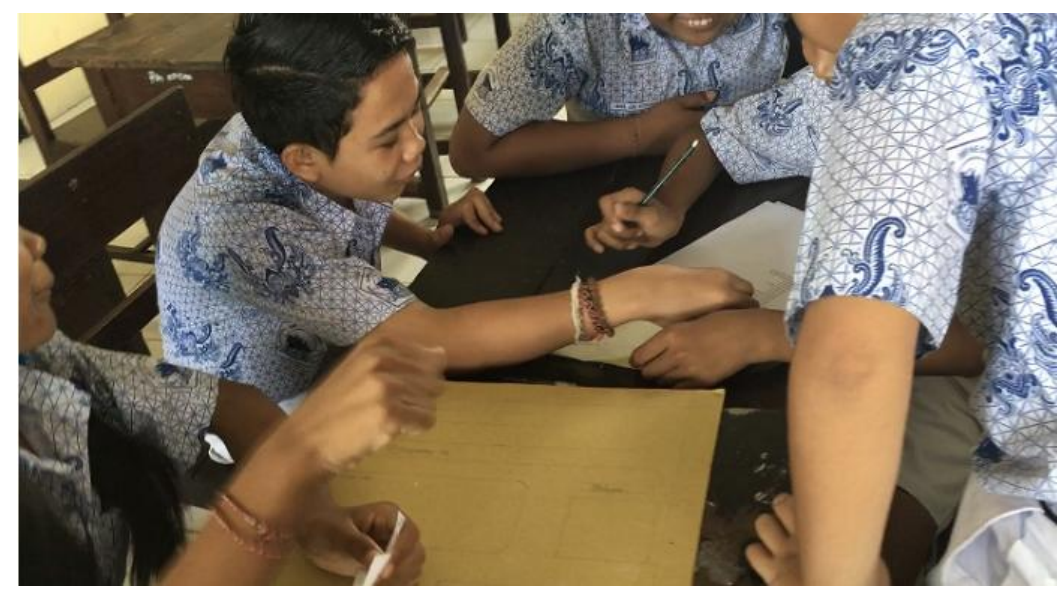

Fig. 4. The students interacted to each other in a group group

Working together is one of the characteristics of PBL implementation. As seen in the picture, students shared their ideas and made a consensus together. They develop their collaborative learning skills which is one of the pillars for the $21^{\text {st }}$ century learning. Imtiaz and Asif (2012) who explored the impact of Project-Based Learning on teaching English found that Project-Based Learning did not only improve students' language skills but also to make them independent learner. In addition, the students also learned some other skills such as doing work as team member, autonomous and independent learning.

From teacher's perspective, PBL promotes self-motivation and satisfaction in teaching. According to Fullan (2001), 
teachers' assumption and expectation for students success is one of the factors that motivates teachers. This research found that the teacher considered PBL as an effective strategy to teach the students and gave positive feedback to students' participation and achievement. Highly engaged teachers result in more engaged students' participation in learning (Demir, 2011). When a teacher believes PBL is beneficial and has good influence to students, it can be expected that s/he are motivated to implement this learning model in their classroom (Lam, et al., 2010; English, 2013). This research also found that the English teacher had strong motivation to implement PBL in the classroom for three reasons: first, the students were fully engaged in the classroom activities so that student-centered learning came into play; second, the students showed good responses toward the learning process; and finally, the teacher had the feeling of satisfaction as the results of positive responses of the students and the conducive learning atmosphere. These are presented in the following excerpt from the teacher.

"Students seem to be so happy and their response to the project-based learning activity is very good. It becomes the most satisfying thing for me if the students are willing to participate actively in the class and achieve the goal of learning. They think that the activities are very interesting. This is why they become very active in the classroom" (T07)

This finding is consistent with Vicheanpant and Ruenglertpanyakul (2012) who pointed out teachers' satisfaction as one of the advantages of PBL in teaching communication skills to the students. Thus, up to this point, PBL does not only affect students' learning positively, but also affect teachers' teaching quality. There seem a strong cause and effect relationship of PBL and student learning: active and participative students affect teachers' motivation and satisfaction, and vise versa. This surely restores the joy of teaching and learning Larmer, Mergendoller, and Boss, 2015).

\section{CONCLUSION}

This study provides empirical evidence of the impact of the implementation of problem-based learning activities on students' speaking and writing skills in English as a foreign language classes. The findings show a significant difference on students' English productive skills before and after being taught by using PBL. In addition, PBL enhances students learning quality in term of enthusiasm, confidence, creativity, self-directed and collaborative learning ability, while from the teacher's part, PBL promotes teacher's motivation and satisfaction in teaching.

Some practical advices are also provided based on the result of this study. Considering the significant effect of PBL on students' English productive skills, it is recommended that PBL should become a choice for English teachers, especially in the context of English as a Foreign Language setting. This teaching method can also promote the teaching and learning quality which has valuable contribution to student learning and support the 21 st century learning.

\section{REFERENCES}

[1] Abdullah, M. N. L. Y., Bin Osman, S., Shamsuddin, M. A., Yusoff, M. S. B., \& Ismail, H. N. (2012). Training module series: Student-Centered Learning. Approaches of innovative teaching. Module 2: Philosophy of students-centered learning (SCL). Malaysia, Universiti Sains Malaysia: Centre for Development of Academic Excellence (CDAE).

[2] Attard, A., Di Iorio, E., Geven, K., \& Santa, R. (2010). Student-Centred Learning: Toolkit for Students, Staff and Higher Education Institutions. Bucharest: European Students' Union (NJ1).

[3] Barron, B. J., Schwartz, D. L., Vye, N. J., Moore, A., Petrosino, A., Zech, L., \& Bransford, J. D. (1998). Doing with understanding: Lessons from research on problem-and project-based learning. Journal of the Learning Sciences, 7(3-4), 271311.

[4] Bell, S. (2010). Project-based learning for the 21st century: Skills for the future. The Clearing House, 83(2), 39-43.

[5] Blank, W. E., \& Harwell, S. (1997). Promising Practices for Connecting High School to the Real World. Tampa, FL: University of South Florida, 15-21.

[6] Blumenfeld, P. C., Soloway, E., Marx, R. W., Krajcik, J. S., Guzdial, M., \& Palincsar, A. (1991). Motivating project-based learning: Sustaining the doing, supporting the learning. Educational psychologist, 26(3-4), 369-398.

[7] Brown, J. K. (2008). Student-centered instruction: Involving students in their own education. Music Educators Journal, 94(5), 30-35.

[8] Carnine, D. (2000). Why education experts resist effective practices (and what it would take to make education more like medicine). Washington, D.C.: Thomas B. Fordham Foundation.

[9] Celce-Murcia, M., Dornyei, Z., \& Thurrell, S. (1995). Communicative competence: A pedagogically motivated model with content specifications. Issues in Applied linguistics, 6(2), 5-35.

[10] Christenson, S. L., Ysseldyke, J. E., \& Thurlow, M. L. (1989). Critical instructional factors for students with mild handicaps: An integrative review. Remedial and Special Education, 10(5), 21-31.

[11] Clark H., M., \& Clark, E., V. (1977). Psychology and Language: An Introduction to Psycholinguistics . New York: Harcourt Brace Jovanovich.

[12] Demir, K. (2011). Teachers' instrinsic and extrinsic motivation as predictors of students engagement: an application of selfdetermination theory. e-Journal of New World Sciences Academy 6.2, 1397-1409.

[13] Dewey, J. (1938). Experience and Education. New York: Collier Books.

[14] Dickinson, K. P., Soukamneuth, S., Yu, H. C., Kimball, M., D'amico, R., Perry, R.,\& Curan, S. P. (1998). Providing Educational Services in the Summer Youth Employment and Training Program. Technical Assistance Guide. http://www.eric.ed.gov/PDFS/ED420756.pdf (accesed 27/9/2016).

[15] English, M. C. (2013). The role of newly prepared PBL teachers' motivational beliefs and perceptions of school conditions in their project based learning implementation. Fairfax, VA: George Mason University. 
[16] Erdem, E. (2012). Examination of the effects of project based learning approach on students' attitudes towards chemistry and test anxiety. World Applied Sciences Journal.17(6). 764-769.

[17] Ferti, E. B. , Adiyalmon, \& Ranti, N. (2014). Faktor Penyebab Rendahnya Motivasi Belajar Siswa Kelas X dalam Pembelajaran Sosiologi di SMA N 4 Kota Solok (Skripsi Program Studi Pendidikan Sosiologi). Indonesia: STKIP PGRI Sumatera Barat Padang.

[18] Fullan, M. (2001). The new meaning of educational change. New York, NY: Teachers College.

[19] Greenhill, V. (2010). 21st Century Knowledge and Skills in Educator Preparation. USA: AACTE.

[20] Guerriero, S. (ed.) (2017). Pedagogical Knowledge and the Changing Nature of the Teaching Profession. Paris: OECD Publishing.

[21] Guven, Z. Z. (2014). Project Based Learning: A Constructive Way Toward Learner Autonomy. International Journal of Languages' Education and Teaching. Turkey: Necmettin Erbakan University Department of Linguistics.

[22] Hadim, H. A., \& Esche, S. K. (2002). Enhancing the engineering curriculum through project-based learning. In Frontiers in education, 2002. FIE 2002. 32nd Annual (Vol. 2, pp. F3F-F3F). Boston: IEEE.

[23] Harmer, J. (1991). The practice of English language teaching 3rd edition. London: New York.

[24] Harmer, J (2007) The Practice of English Language Teaching 4th edition. Harlow: Longman.

[25] Harun, Y. (2006). Project-Based Learning handbook "Educating the Millennial Learner'. Kuala Lumpur: Educational Technology Division Ministry of Education.

[26] Hastuti, L. A. (2016). Analisis Penyebab Rendahnya Kreativitas dan Motivasi Belajar Matematika di SDN 04 Tegalgede Tahun 2015 (Doctoral dissertation, Universitas Muhammadiyah Surakarta). Indonesia: Universitas Muhammadiyah Surakarta.

[27] Henter, R. (2014). Affective factors involved in learning a foreign language. Procedia-Social and Behavioral Sciences, 127, 373-378.

[28] Imtiaz, S. \& Asif, S. I. (2012). " I almost learnt to learn": Promoting Learner's Autonomy through Project Based Learning in Access Classrooms. Language in India 12.1, 24-45.

[29] Indonesia, P. R. (2005). Peraturan Pemerintah Republik Indonesia Nomor 19 Tahun 2005 Tentang Standar Nasional Pendidikan. Departemen Pendidikan Nasional Republik Indonesia.

[30] Jerald, C. D. (2009). Defining a 21st century education. Alexandria, VA: Center for Public Education.

[31] Kaptan, F., \& Korkmaz, H. (2001). Fen eğitiminde probleme dayalı öğrenme yaklaşımı. Hacettepe Üniversitesi Eğitim Fakültesi Dergisi 20, 185-192.

[32] Kember, D. (2009). Promoting student-centred forms of learning across an entire university. Higher Education 58.1, 1-13.

[33] Knowles, M. S. (1984). Andragogy in action (pp. 1-21). San Francisco: Jossey-Bass.

[34] Lam, S. F., Cheng, R. W. Y., \& Choy, H. C. (2010). School support and teacher motivation to implement project-based learning. Learning and Instruction, 20.6, 487-497.

[35] Larmer, J., Markham, T., \& Ravitz, J. (2003). Project-based learning handbook. Oakland, CA: Wilsted and Taylor.

[36] Larmer, J., Mergendoller, J., \& Boss, S. (2015). Setting the standard for project based learning. Alexandria, VA: ASCD.

[37] Luke, A. (2013). Back to the future. The Australian Educator, Summer 80, 14-15.

[38] Markham, T. (2011). Project Based Learning. Teacher Librarian, 39(2), 38-42.

[39] Masrom, U., \& Yusof, D. S. M. (2013). English Games as a Constructivist Approach in Project Based Learning. International Journal of Social Science and Humanities Research 1.1, 21-25.

[40] Miles, M. B., \& Huberman, A. M. (1994). Qualitative data analysis: An expanded sourcebook. London: SAGE Publications Inc.

[41] Nassir, S. (2014). The Effectiveness of Project-based Learning Strategy on Ninth Graders' Achievement Level and their Attitude towards English in Governmental Schools -North Governorate (Master Thesis). Gaza: The Islamic University.

[42] Ndon, U. (2011). Hybrid-Context Instructional Model: The Internet and the Classrooms: The Way Teachers Experience It. Information Age Publishing Inc. The USA. 28th Annual Conference on Distance Teaching \& Learning

[43] Poplin, M. S. (1988). Holistic/constructivist principles of the teaching/learning process: Implications for the field of learning disabilities. Journal of learning Disabilities, 21(7), 401-416.

[44] Pradanar, B. W. (2014). Analisis Faktor-Faktor Penghambat Dan Pendukung Implementasi Kurikulum 2013 Untuk Mata Pelajaran Ekonomi Di Sma Se-Kota Pasuruan (Skripsi Jurusan Ekonomi Pembangunan-Fakultas Ekonomi). Indonesia: Universitas Negeri Malang.

[45] Rochmahwati, P. (2016). Project-based learning to raise students' speaking ability: its' effect and implementation (a mix method research in speaking II subject at STAIN Ponorogo). Kodifikasia, 9(1), 199-222.

[46] Sadeghi, H., Biniaz, M., \& Soleimani, H. (2016). The Impact of Project-Based Language Learning on Iranian EFL Learners Comparison/Contrast Paragraph Writing Skills. International Journal of Asian Social Science, 6(9), 510-524.

[47] Spratt, M., Pulverness, A., \& Williams, M. (2005). The teaching knowledge test course. Cambridge: CUP.

[48] Stainback, W., \& Stainback, S. (1992). Controversial Issues Confronting Special Education: Divergent Perspectives. Allyn and Bacon, 160 Gould St., Needham Heights, MA 02194-2310.

[49] Steffe, L. P., \& Gale, J. E. (Eds.). (1995). Constructivism in education (p. 159). Hillsdale, NJ: Lawrence Erlbaum.

[50] Stoller, F. L. (1997). Project Work: A Means to Promote Language Content. English Teaching Forum 35.4, 2-16

[51] Talat, A., \& Chaudhry, H. F. (2014). The Effect of PBL and 21st Century Skills on Students' Creativity and Competitiveness in Private Schools. The Lahore Journal of Business, Spring 2.2, 89-114.

[52] Thomas, J. W. (2000). A review of research on project-based learning. California: The Autodesk Foundation.

[53] Vicheanpant, T., \& Ruenglertpanyakul, W. (2012). Attitude about project-based learning and lecture based for develop communication skill. European Journal of Social Sciences, 28(4), 465-472.

[54] Weegar, M. A., \& Pacis, D. (2012). A Comparison of Two Theories of Learning-Behaviorism and Constructivism as applied to Face-to-Face and Online Learning. In Proceedings E-Leader Conference, Manila. https://www.gcasa.com/conferences/manila/ppt/Weegar.pdf (accessed 13/11/2016).

[55] Weld, J., \& Funk, L. (2005). "I'm not the science type": Effect of an inquiry biology content course on preservice elementary teachers' intentions about teaching science. Journal of science teacher education, 16(3), 189-204. 
[56] Westwood, P. S. (2008). What teachers need to know about teaching methods (Aust Council for Ed Research). Victoria: Acer Press.

[57] Wulandari, R. (2014). Improving students' speaking ability through communicative language games at SMPN 1 Prambanan grade VIII A in the academic year of 2013/2014 (Doctoral dissertation). Indonesia: Universitas Negeri Yogyakarta.

[58] Yaman, B. (2015). Pelaksanaan Metode Active Learning Dalam Meningkatkan Hasil Belajar Siswa Pada Pembelajaran Pendidikan Agama Islam (Studi Kasus Siswa Kelas X SMKN 9 Surakarta Tahun Pelajaran 2014/2015) (Doctoral dissertation). Indonesia: Universitas Muhammadiyah Surakarta.

[59] Yang, D. \& Puakpong, N. (2016). Effects of project-based learning on speaking abilities of Non-English major Chinese students. Proceedings of the Seventh CLS International Conference CLaSIC 2016. https://www.fas.nus.edu.sg/cls/CLaSIC/clasic2016/PROCEEDINGS/yang_di.pdf (accessed 9/10/2016).

[60] Zhao, Y. (2009). Catching up or leading the way: American education in the age of globalization. Alexandria, VA: ASCD.



Ni Luh Putu Ning Septyarini Putri Astawa is a student of Postgraduate Program in English Education Department, Faculty of Language and Arts, Ganesha University of Education (UNDIKSHA), Bali, Indonesia. She obtained her Bachelor degree in English Language Teaching in 2015.

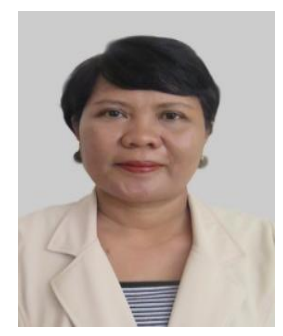

Luh Putu Artini is a teaching staff at the English Education Department, Faculty of Language and Arts, Ganesha University of Education (UNDIKSHA), Bali, Indonesia. She earned her master degree from La Trobe University, Australia in 1994, and doctoral degree in English Education from Newcastle University, Australia in 2006. Artini is an active researcher and have won many competitive grants. She has been an invited speaker in many academic events and teacher's forums all around Bali and neighboring provinces.

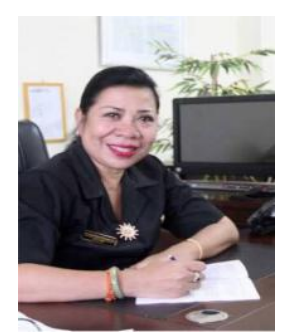

Putu Kerti Nitiasih is the Dean of the Faculty of Language and Arts, Ganesha University of Education, Bali, Indonesia. She earned her master degree from Sydney University, Australia in 1994, and doctoral degree in Linguistics from Udayana University, Indonesia in 2006. She is an active researcher and has been a trainer in the area of linguistics and English Language Teaching in Indonesia. 